\title{
A Cordaixylon axis from well-drained alluvial plain facies in the Lower Pennsylvanian Joggins Formation of Nova Scotia
}

\author{
HowARD J. FALCON-LANG \\ Department of Earth Sciences, University of Bristol, Bristol BS8 1RJ, United Kingdom \\ < howard.falcon-lang@bris.ac.uk>
}

Date received, 20 February 2007 Date accepted 17 April 2007

\begin{abstract}
Plant remains showing preservation of cellular anatomy are rare in the Lower Pennsylvanian Joggins Formation of Nova Scotia. Here I report an anatomically preserved cordaitalean axis that shows endarch maturation and a sympodial vascular architecture. The specimen belongs to the morphogenus Cordaixylon, but in the absence of extraxylary tissue or attached fertile material, it cannot be assigned to a species. Together with a previously reported Mesoxylon axis with mesarch and non-sympodial vasculature, the new discovery demonstrates the existence of both major organizational types of cordaitalean at this locality. Previous reports have identified Cordaixylon as a plant that preferred peat mire environments. In this paper, the morphogenus is recorded from well-drained alluvial plain facies, thus extending knowledge of its ecological range.
\end{abstract}

\section{RÉSUMÉ}

Les vestiges de plantes présentant une préservation de l'anatomie cellulaire sont rares à l'intérieur de la Formation du Pennsylvanien inférieur de Joggins, en Nouvelle-Écosse. Je fais part dans les présentes d'un axe de cordaitaléen anatomiquement préservé qui affiche une maturation circulaire à partir de l'intérieur et une architecture vasculaire sympodiale. Le spécimen fait partie du morphogenre Cordaixylon, mais en l'absence de tissu extraxylaire ou de matière fertile y étant fixée, on ne peut pas le rattacher à une espèce donnée. La nouvelle découverte, conjuguée à un axe de Mesoxylon précédemment signalé qui comportait une vasculature non sympodiale à éléments en spirale internes, révèle l'existence des deux principaux types structuraux de cordaitaléens à cet emplacement. Des rapports antérieurs avaient défini le Cordaixylon en tant que plante préférant les environnements à bourbiers de tourbe. Le présent document fait état de l'observation du morphogenre d'un faciès de plaine alluviale bien drainée, ce qui étend notre connaissance de son aire de distribution écologique.

\section{[Traduit par la redaction]}

\section{INTRODUCTION}

The Cordaitales are a Late Palaeozoic order of gymnosperms closely related to conifers and characterized by strap-shaped leaves, dense, pycnoxylic wood, axillary branching, and flat, platyspermic seeds (Rothwell 1988). The overall diversity of this group is probably greatly underestimated because Cordaites leaves (the most commonly preserved organ) show a highly conservative morphology (Šimůnek 2000; Zodrow et al. 2000). In palaeotropical Euramerica, where cordaitalean ecology is best understood, plants include forms that grew in lagoons, peat mires, coastal plains, alluvial fans, and in mountainous terrains (Falcon-Lang and Bashforth 2005).

Cordaitaleans are very common in the Lower Pennsylvanian Joggins Formation of Nova Scotia (Latitude $45^{\circ} 42^{\prime} \mathrm{N}$;
Longitude $64^{\circ} 26^{\prime} \mathrm{W}$; Fig. 1; Falcon-Lang et al. 2006). A small number of cordaitalean fossils, especially those found in welldrained alluvial plain facies (Davies and Gibling 2003), show anatomical preservation as calcite permineralizations and charcoal (Falcon-Lang and Scott 2000). These fossils include three morphospecies of pycnoxylic Dadoxylon wood (FalconLang 2003a) and a woody axis showing mesarch maturation and a non-sympodial vasculature assigned to Mesoxylon, cf. M. sutcliffii (Falcon-Lang 2003b). Here I describe a new cordaitalean axis from the Joggins Formation that differs from material previously reported insofar as that it shows endarch maturation and a sympodial vasculature. It is assigned to the morphogenus Cordaixylon. 


\author{
SYSTEMATICS \\ Class Coniferopsida \\ Order Cordaitales \\ Genus Cordaixylon Grand'Eury, 1877 \\ Cordaixylon sp.
}

(Fig. 2A-L)

\section{Description}

The specimen is a slender axis with a diameter of $11.5 \mathrm{~mm}$ and a length of $21 \mathrm{~mm}$. The axis comprises a $6 \mathrm{~mm}$ diameter pith surrounded by a xylem cylinder, 2.5-3.0 mm radius; no extraxylary tissue is preserved (Fig. 2A, B). The pith is solid (non-septate) and constructed of equant to platy parenchyma cells, 45-90 $\mu \mathrm{m}$ (locally up to $150 \mu \mathrm{m}$ ) in diameter, which locally show pitting (Fig. 2C), contain dark material, and are arranged in irregular, vertical columns, especially near the margin of the pith (Fig. 2G).

Primary xylem exhibits endarch maturation (Fig. 2F) and is composed of 6-15 $\mu$ m diameter tracheids that show an outward (centrifugal) progression from scalariform to locally reticulate thickening (Fig. 2H). Vasculature is sympodial with bundles running parallel to the pith for up to $11 \mathrm{~mm}$ before dividing in two, one bundle departing as a sub-horizontal leaf trace, the other rejoining the sympodial complex at the same level (Fig. 2D, E). Adjacent bundles are not interconnected. Leaf traces are 350-400 $\mu \mathrm{m}$ in diameter, and remain undivided from the margin of pith to the edge of the secondary xylem (Fig. 2B). The specimen is too incompletely preserved to determine phyllotaxis, although leaf arrangement was helical.

Secondary xylem comprises $14-22 \mu \mathrm{m}$ tracheids that show 1-2 (locally up to 3) seriate, alternately arranged bordered pitting on radial walls (Fig. 2I). Pits are hexagonal, contiguous, and 7-8 $\mu \mathrm{m}$ in diameter with a $4-5 \mu \mathrm{m}$ aperture. Cross-field regions show 1-6 oval, araucarioid pits with indistinct borders (Fig. 2J). Tangential tracheids walls are blank. Rays are uniseriate, 1-5 (locally up to 15) cells high, and spaced 1-5 tracheids apart (Fig. $2 \mathrm{~K})$. No growth rings were observed in the 2.5-3.0 mm radius of secondary xylem preserved (Fig. 2A, L).

\section{Remarks}

The Cordaixylon specimen was found by the author within a large block of red sandstone lying on the foreshore, a few hundred metres south of Little River, near Joggins (Fig. 1B). Rocks exposed in the adjacent cliff section comprise a thick interval of red mudstone and sandstone, 230-280 m above the base of the Joggins Formation (Davies et al. 2005; FalconLang et al. 2006); this section represents the probable interval of origin for the new specimen. The specimen is stored in the collections of the Nova Scotia Museum, 1747 Summer Street, Halifax, Nova Scotia B3H $3 \mathrm{~A} 6$ under accession number NSM006GF035.001.

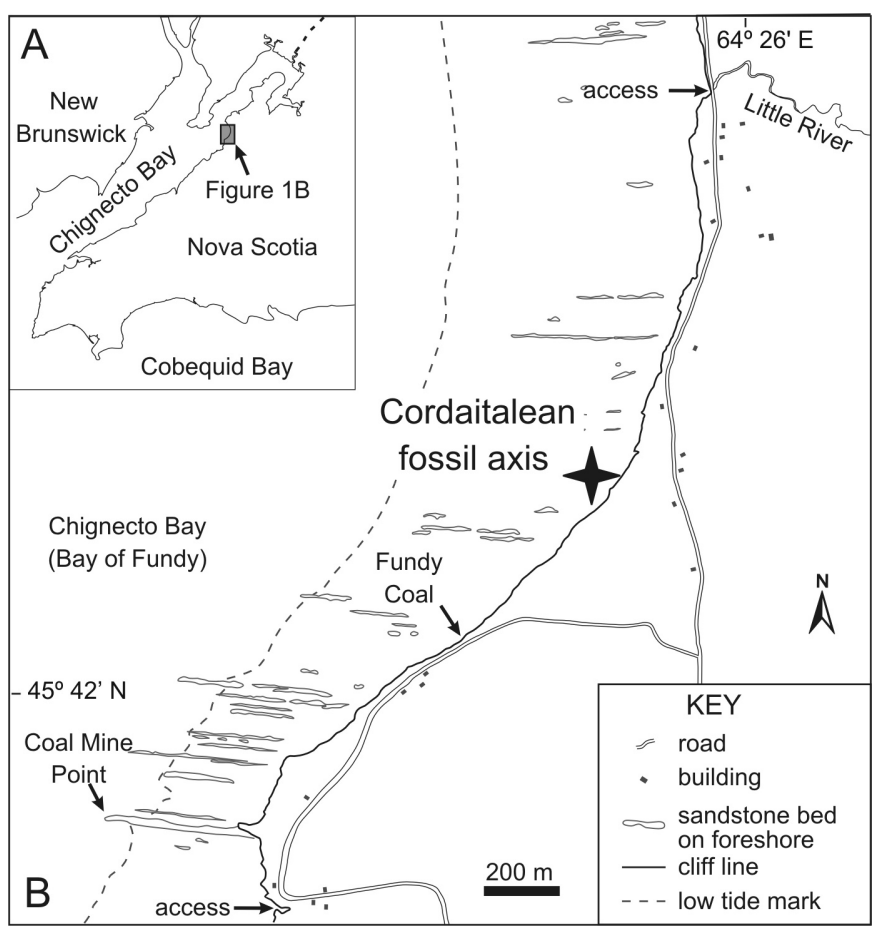

Fig. 1 Location details. (A) Position of Joggins on Chignecto Bay, Nova Scotia, Canada, (B) Map of Joggins foreshore showing the location of the Cordaixylon specimen (indicated by black star) described in this paper.

\section{DISCUSSION}

The systematics of cordaitalean axes is currently in need of revision. The traditional approach, still widely used, involves the separation of morphogenera based on the type of primary xylem maturation and cauline vascular architecture (Scott and Maslen 1910; Traverse 1950; Trivett and Rothwell 1988). Two morphogenera are recognized in this system: the Cordaixylon concept comprises axes showing endarch maturation and sympodial vasculature (Rothwell and Warner 1984), whereas the Mesoxylon concept comprises mesarch maturation and nonsympodial vasculature (Trivett and Rothwell 1985). However, specimens have been reported that show overlapping suites of characters raising problems for this approach (Trivett and Rothwell 1988, 1991). Although cladistic analyses attempted to resolve the position of these specimens (Trivett 1992), the systematics of cordaitalean axes remains problematic.

Following the tradition approach, the new specimen from the Joggins Formation falls within the Cordaixylon concept (Rothwell and Warner 1984; Trivett 1992), being endarch with a sympodial vasculature (Fig. 2D-F). Unlike the new specimen (Fig. 2A, B), Cordaixylon axes commonly show a septate pith, although a solid parenchymatous pith is seen in basal or apical regions of some axes, as well as being the normal characteristic of the roots (Rothwell and Warner 1984; Constanza 1985; Trivett 1992). In the absence of extraxylary tissues (Fig. 2A), or any information concerning attached fertile organs, it is impossible to assign the new material to a species. If found in isolation, the secondary xylem of the new specimen of 


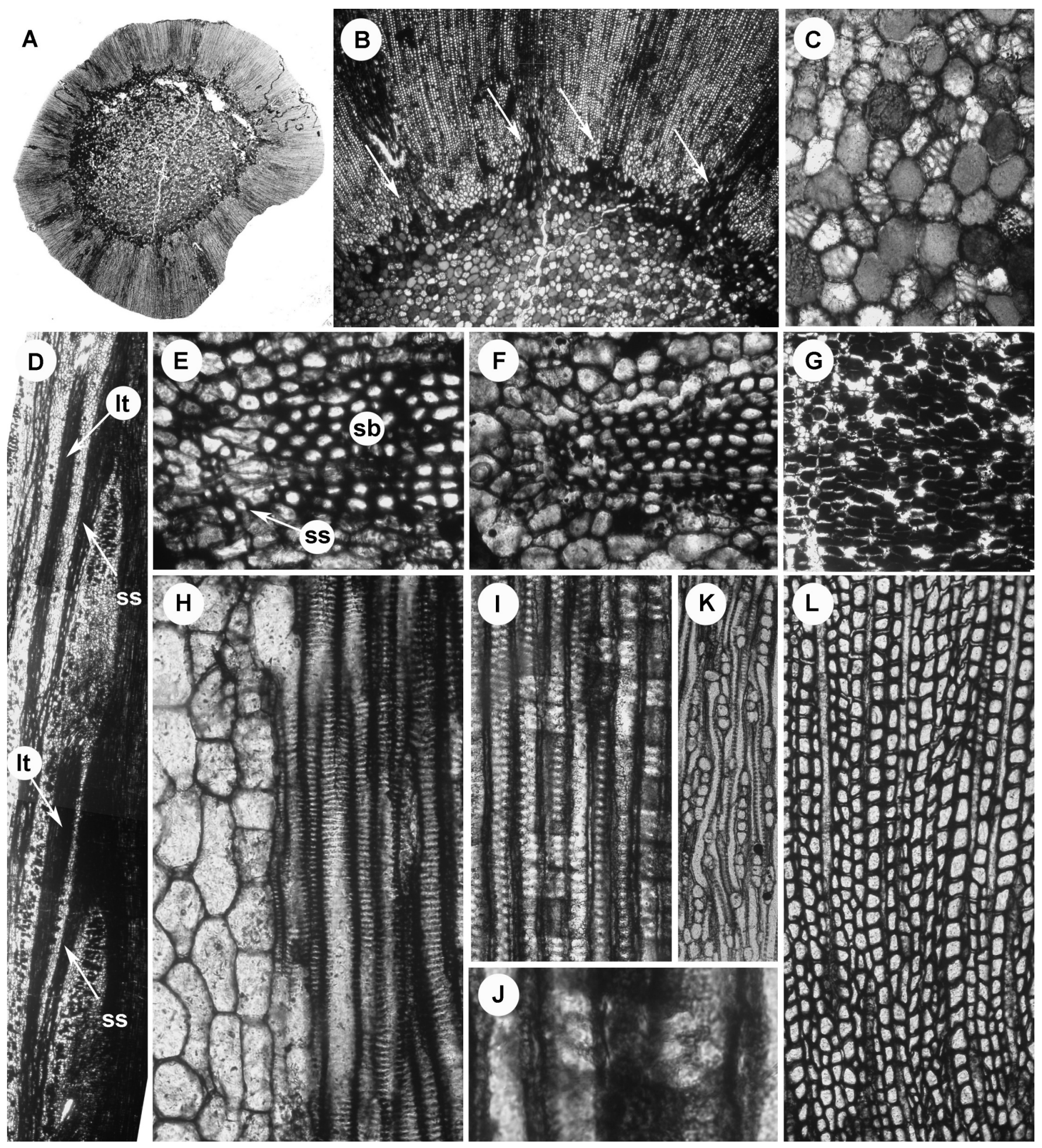

Fig. 2 Anatomy of Cordaixylon axis; Nova Scotia Museum specimen number NSM006GF035.001. (A) General view of axis showing parenchymatous pith (non-septate in RLS, not shown) and xylem cylinder, TS, $\mathrm{x} 5$; (B) cross-section of axis showing leaf trace departures (arrowed), TS, x15; (C) parenchyma cells in pith showing pitting, TS, x100;(D) primary vasculature showing sympodial bundles dividing into two, one strand departing as a leaf trace (lt), the other sympodial strand (ss) rejoining to the bundle, photomontage, RLS, x10; (E) endarch sympodial strand (ss) just below the level that it rejoins the sympodial bundle (sb), TS, x300; (F) endarch sympodial bundle, TS, x300; (G) vertical columns of parenchyma showing dark contents in pith, RLS, x50; (H) primary xylem showing scalariform thickening (right) adjacent to pith (left), RLS, x500; (I) tracheids with 1-2-seriate bordered pitting and uniseriate rays in the secondary xylem, RLS, x250; (J) araucarioid cross-field pitting, RLS, x1000, (K) short, uniseriate rays, TLS, x250; and (L) secondary xylem, TS, x200. 
Cordaixylon would be referred to Dadoxylon recentium; this morphogenus is locally present in the Joggins Formation (Falcon-Lang 2003a).

The new discovery broadens knowledge of cordaitalean plant diversity in the Joggins Formation. Adding to the previously reported occurrence of Mesoxylon showing mesarch and non-sympodial organisation (Falcon-Lang 2003b), the Cordaixylon specimen proves the existence of cordaitaleans with endarch and sympodial organization at this locality for the first time. Furthermore, the association of the new specimen with red bed facies, interpreted as well-drained alluvial plain deposits (Davies et al. 2005), improves knowledge of cordaitalean ecology in general. Remains of Cordaixylon wholeplants are extremely abundant in some Pennsylvanian coals in the USA, where they flourished as peat mire trees (DiMichele and Phillips 1994). Here I show that at least some Cordaixylon whole-plants were capable of existing in dryland environments as well (Falcon-Lang et al. 2004).

\section{ACKNOWLEDGEMENTS}

I gratefully acknowledge receipt of the Tyrell Fund of the Geological Society of London, which supported fieldwork at Joggins, and during which time I collected the new specimen. I thank Simon Powell (University of Bristol) for help with photography. The reviews of Bill DiMichele and John Calder greatly improved this paper, as did the thorough editorial work of Rob Fensome.

\section{REFERENCES}

Costanza, S.H. 1985. Pennsylvanioxylon of Middle and Upper Pennsylvanian coals from the Illinois Basin and its comparison with Mesoxylon. Palaeontographica B, 197, pp. 81-121.

Davies, S.J., AND Gibling, M.R. 2003. Architecture of coastal and alluvial deposits in an extensional basin: the Carboniferous Joggins Formation of eastern Canada. Sedimentology, 50, pp. 415-439.

Davies, S.J., Gibling, M.R., Rygel, M.C., And Calder, J.H. 2005. The Joggins Formation: stratigraphic framework and sedimentological log of the historic fossil cliffs. Atlantic Geology, 41, pp. 115-141.

Dimichele, W.A., And Phillips, T.L. 1994, Palaeobotanical and palaeoecological constraints on models of peat formation in the Late Carboniferous of Euramerica. Palaeogeography, Palaeoclimatology, Palaeoecology, 106, pp. 39-90.

Falcon-LANG, H.J. 2003a. Late Carboniferous tropical dryland vegetation in an alluvial plain setting, Joggins, Nova Scotia, Canada. Palaios, 18, pp. 197-211.

FALCON-LANG, H.J. 2003b. Anatomically-preserved cordaitalean trees from Lower Pennsylvanian (Langsettian) dryland alluvial-plain deposits at Joggins, Nova Scotia. Atlantic Geology, 39, pp. 255-261.

FAlCon-LANG, H.J. AND BASHForth, A.R. 2005. Morphology, anatomy, and upland ecology of large cordaitalean trees from the Middle Pennsylvanian of Newfoundland. Review of Palaeobotany and Palynology, 135, pp. 223-243.

FALCON-LANG, H.J. AND ScotT, A.C. 2000. Upland ecology of some Late Carboniferous cordaitalean trees from Nova Scotia and England. Palaeogeography, Palaeoclimatology, Palaeoecology, 156, pp. 225-242.

Falcon-Lang, H.J., Rygel, M., Calder, J.H., and Gibling, M.R. 2004. An early Pennsylvanian waterhole deposit and its fossil biota in a dryland alluvial plain setting, Joggins, Nova Scotia. Journal of the Geological Society, London, 161, pp. 209-222.

Falcon-Lang, H.J., Benton, M.J., Braddy, S.J., and Davies, S.J. 2006. The Pennsylvanian tropical biome reconstructed from the Joggins Formation of Canada. Journal of the Geological Society, London, 163, pp. 561-576.

Grand'Eury, F.C. 1877. Mémoire sur la flore carbonifère du département de la Loire et du centre de la France, étudiée aux trois points de vue botanique, stratigraphique et géognostique. Mémoires de l'Académie des Sciences de l'Institut de France, 24, pp. 1-624.

Rothwell, G.W. 1988. Cordaitales. In Origin and Evolution of Gymnosperms, Edited by C.B. Beck. Columbia University Press, New York, pp. 273-297.

RothWell, G.W., AND WARNER, S. 1984. Cordaixylon dumusum n. sp. (Cordaitales). I. Vegetative structures. Botanical Gazette, 145, pp. 275-291.

Scott, D.H., AND Maslen A.J. 1910. On Mesoxylon, a new genus of Cordaitales: preliminary note. Annals of Botany, 24, pp. 236-239.

ŠIMŮNEK, Z. 2000. Cuticles of Cordaites from the Westphalian, Stephanian and Autunian of the Bohemian Massif (Czech Republic): a preliminary study. Acta Palaeobotanica, 40, pp. 25-34.

Traverse, A. 1950. The primary vascular body of Mesoxylon thompsonii, a new American cordaitalean. American Journal of Botany, 37, pp. 318-325.

TrivetT, M.L. 1992. Growth architecture, structure, and relationships of Cordaixylon iowensis nov. comb. (Cordaitales). International Journal of Plant Sciences 153, pp. 273-287.

Trivett, M.L., And Rothwell, G.W. 1985. Morphology, systematics, and palaeoecology of Palaeozoic fossil plants: Mesoxylon priapi, sp. nov. (Cordaitales). Systematic Botany, 10, pp. 205-223.

TrivetT, M.L., AND Rothwell, G. W. 1988. Diversity among Paleozoic Cordaitales: the vascular architecture of Mesoxylon birame Baxter. Botanical Gazette, 149, pp. 116-125.

TrivetT, M.L., AND Rothwell, G.W. 1991. Diversity among Paleozoic Cordaitales. Neues Jahrbuch für Geologie und Paläontologie, Abhandlungen, 183, pp. 289-305.

Zodrow, E., SimŮNeK, Z., AND BASHForTh, A.R. 2000. New cuticular morphotypes of Cordaites principalis from the Canadian Carboniferous Maritimes Basin. Canadian Journal of Botany, 78, pp. 135-148.

Editorial responsibility: Robert A. Fensome 